\title{
Internationalization of Universities: 70 Years of Experience
}

\author{
Vladimir Filippov
}

The creation of the IAU 70 years ago was one of the consequences of evolving international life following the Second World War. This featured the evolution of organizations such as the United Nations, UNESCO, the Council of Europe and the European Union. In higher education, new international policies led to the internationalization of universities (Altbach 2010). From the beginning, the IAU became one of the international platforms where universities exchanged experiences and built relations. In the acting strategy of IAU adopted in 2016, internationalization is one of the four priorities.

RUDN University, where about ten thousand (about 40\%) international students from more than 150 countries have been studying for decades, has extensive experience in internationalizing various aspects of life now relevant for many universities in the world.

If we do not consider ad hoc programs and training elite international students in universities, massive internationalization of universities went through the following stages.

\section{Stage $1(1950-1970)$}

As a result of the democratization of international life after the Second World War and the emergence of newly independent states, developed countries began a massive admission of international students to universities to train specialists for newly developing countries. While aiding developing countries, donor countries also solved their geopolitical tasks, since at that time, the world was divided into countries with

\footnotetext{
V. Filippov $(\bowtie)$

RUDN University, Moscow, Russia

e-mail: v.filippov@rudn.ru

(C) The Author(s) 2021 
a capitalist and socialist orientation. A key indicator since that period has been the percentage of international students in a university. Currently, in the majority of countries, 5-10\% of international students in a university is considered satisfactory internationalization; 10-15\%—good; 15-20\%—excellent; over 20\%—outstanding.

\section{Stage 2 (1970-1990)}

Starting from the 1970s, confrontation between two ideologies transferred a new scientific and technological revolution to the field; meanwhile various new forms of educational services appeared alongside the tasks of the first stage of university internationalization: international branches of universities, educational programs franchising, joint universities, etc. A significant new element in the internationalization of universities during this period was (Altbach and De Wit 2015) the development of international cooperation and competition in the scientific field: exchange of researchers, including young ones, became systemic; developed countries shifted to keeping the most talented young international students. As a result, by the beginning of the 1990s, international scientific cooperation had become one of the most important factors in the development of universities. Currently, based on an analysis of university monitoring systems in different countries of the world, the presence of more than $5 \%$ of international research and teaching staff in universities is considered a satisfactory indicator, more than $10 \%$ is a good indicator; more than $15 \%$-excellent, and more than $20 \%$ - outstanding.

\section{Stage 3 (1990-2010)}

The processes of internationalization in Higher Education during this period became more dependent on globalization: the previously prevailing bilateral relations and cooperation programs were replaced by various international regional and global networks and unions. As a result, large regional conventions on the recognition of documents in the field of Higher Education began to appear instead of bilateral agreements on the equivalence of documents on education in various countries. For example; the Lisbon Convention of UNESCO/Council of Europe of 1997; agreements on the creation of common spaces of Higher Education (Bologna process in Europe, etc.); harmonization of regional Higher Education Systems (in Latin America, Africa, Asia) with the Bologna process Higher Education structure.

Stage 4 (since 2010) University Internationalization at Home (Domestic Internationalization) this stage tasks the processes of globalization faced by the world community.

In the context of creating modern knowledge-based economies and societies, a new task for modern universities is Universities Internationalization at Home - the massive training of graduates who can work in conditions of global competition, in 
international teams, live and feel tolerant in multinational and multi-faith communities, as well as work in conditions of professional mobility and migration labour resources. These are already tasks aimed not so much at just training foreign students and attracting foreign professors to universities as was important at the previous stages of internationalization - although until now these very indicators have been the main criteria for Internationalization in various World Universities Ranking Systems.

University Internationalization at Home aims (Brandenburg et al. 2019; De Wit et al. 2019) at creating such a sociocultural environment within the university that promotes the development of international and intercultural understanding, provides an international dimension to all educational, research and cultural programs and projects, and includes in all management structures of a Higher Educational Institution the best international practices to improve the quality of teaching and research. Therefore, achieving the necessary competencies and strengthening university management.

To meet the modern challenges that societies and economies pose to universities, namely to prepare graduates to live and work in a globalizing world, the most important task of universities is Altbach and De Wit (2018) to internationalize the vast majority of their domestic students, teachers, and staff. This sets forth serious new requirements on the Internationalization of almost all aspects of university life.

By the year 2010, the new dimension of Internationalization of Higher Education had been sufficiently developed in some countries-the pioneers were universities and the Australian government, which implemented Universities Internationalization at Home as a state policy of an integrated system of measures. As far as European countries are concerned, universities and the Higher Education System of the Netherlands as a whole have advanced most on this path.

The experience of RUDN University as one of the most internationalized universities in the world determines several main activities of Universities Internationalization at Home.

In the field of Education, this includes considering global trends in the implementation of a common framework of qualifications and specialties; exploring and implementing the experience of creating the best examples of educational programs of Higher Education; focusing on the international accreditation of Higher Education programs; and networking between universities, creating joint educational programs, double diploma programs - at least one joint program with a foreign university in each field of study. It also implies shaping international student groups, striving for graduates' fluency in a foreign language (in the field of professional activities), Master students should know at least two foreign languages, one of which is English; massive advanced training of the teaching staff in foreign languages and modern teaching technologies; and ensuring (mandatory) academic mobility of the largest possible share of university students. Finally, Universities Internationalization at Home is introducing interactive methods in the educational process by using global information networks, databases, and MOOCs. 
In the field of Research, Universities Internationalization at Home entails comparative studies; determining priorities and bringing basic research of the university to a level that meets modern requirements in the scientific world; support for international academic mobility of research and teaching staff, especially graduate students and young researchers; active targeted support for the participation of the university and individual researchers in international scientific competitions, projects, and programs; support for publications of researchers in leading foreign journals; and the international cooperation of scientists in the publishing field through international collaborations, where the co-author (co-authors) of the scientific work is a foreign scientist, while co-authorship can be considered not only as a form of scientific collaboration but also an increase in the level of trust in the academic community, a kind of "scientific diplomacy." Also, creating international research laboratories and centres; creating international Advisory and Expert bodies on research and educational policy issues; - hiring talented foreign graduates for scientific work at university; conducting mainly international scientific conferences at the university, with targeted involvement of representatives of the most respected foreign research teams; and actively using information and communication networks for the international activities of university research teams, are all relevant activities for the internationalization of research.

In the field of Attitude Development of Students, Teachers, and Employees RUDN University aims to provide a purposeful attitude among students, teachers, and employees to recognize the values of world cultures and respect the traditions and customs of other peoples and faiths. Taking into account national specifics (primarily in the field of nutrition and healthy lifestyle) concerning the university infrastructure by involving students in various multinational groups in the extracurricular activities of the university (cultural, sports, etc.), develop students' tolerance and ability to work in multinational groups, and provide conditions for tolerance on student campuses, mainly on the principle of placing students of different nationalities in a shared dorm room and creating a student code of conduct. International standards considering the tasks of international teams and the need for active international activities of the university are also considered relevant to the Universities Internationalization at Home policy.

Finally, in the field of Management and Finance, internationalization implies involving qualified foreign representatives in managerial and research structures of the university; conducting regular international audits of various areas of the university; and creating open (in accordance with international criteria) university websites in foreign languages. It also entails promoting the presence of the university and its scientists on the internet, including profiles in foreign languages; diversifying university activities to attract extra-budgetary funds through various forms of international activity of the university and its researchers; and, eventually, introducing progressive forms of university autonomy, defined in accordance with international criteria conditions for the sustainable development status of the university. 
The ongoing advisory visits by IAU experts to various universities around the world allow for the exchange of the practical experience of universities and increasing appropriate level of competencies of universities interested in promoting internationalization. Even RUDN University, having 60 years of experience of internationalization, significantly modernized its policies and technologies for the University's internal internationalization following a visit by IAU experts.

At the same time, comparing the experiences of university internationalization in the world requires serious analytical and comparative research to determine the most effective methods of internationalization, taking into account the specific missions and challenges faced by the university. In this regard, in 2020-2022, RUDN University is implementing a project to create a portal to summarize the experience of internationalizing leading universities of the world-a project that can provide invaluable support to all IAU member universities in accordance with the strategic objectives and the above-mentioned IAU activities.

\section{References}

Altbach, P.G. (2010). The Realities of Mass Higher Education in a Globalized World. In D. B. Johnstone., M. B. d'Ambrosio \& P. J. Yakoboski (Eds.), Higher Education in a Global Society (pp. 25-41), Edward Elgar Publishing.

Altbach P.G., \& De Wit, H. (2015). Internationalization and Global Tension: Lessons from History. Journal of Studies in International Education 19(1), 4-10.

Altbach P.G. \& De Wit, H. (2018. February 23). The Challenge to Higher Education Internationalisation. University World News. Retrieved from: https://www.universityworldnews.com/post. php?story $=20180220091648602(26.07 .2020)$

Brandenburg, U., De Wit, H., Jones, E., \& Leask, B. (2019. June 26). Defining Internationalisation in Higher Education for Society. University World News. Retrieved from: https://www. universityworldnews.com/post.php?story=20190626135618704 (26.07.2020)

De Wit, H., Rumbley, L.R., Craciun, D., Mihut, G., \& Woldegiyorgis, A. (2019. May 1). International Mapping of National Tertiary Education Internationalization Strategies and Plans (NTEISPs). Center for International Higher Education (CIHE), 12. Retrieved from: https://www.bc.edu/ content/dam/bc1/schools/lsoe/sites/cihe/publication/pdf/Perspectives\%2012.pdf (26.07.2020)

Vladimir Filippov is President of RUDN University and professor of Mathematics. He has served as Minister of Education in Russia (1998-2004), Chairman of Organizing Committee (20072009) and President of World Higher Education Conference (UNESCO, 2009). Since 2010, he was Chairman and up to now Member of Steering Committee of UNESCO World Programs "Education for All" and "Education - 2030". 
Open Access This chapter is licensed under the terms of the Creative Commons Attribution 4.0 International License (http://creativecommons.org/licenses/by/4.0/), which permits use, sharing, adaptation, distribution and reproduction in any medium or format, as long as you give appropriate credit to the original author(s) and the source, provide a link to the Creative Commons license and indicate if changes were made.

The images or other third party material in this chapter are included in the chapter's Creative Commons license, unless indicated otherwise in a credit line to the material. If material is not included in the chapter's Creative Commons license and your intended use is not permitted by statutory regulation or exceeds the permitted use, you will need to obtain permission directly from the copyright holder. 